\title{
How Can We Improve Online Learning at Community Colleges? Voices from Online Instructors and Students
}

\author{
Qiujie Li \\ New York University \\ Xuehan Zhou \\ University of California, Irvine \\ Brad Bostian \\ Central Piedmont Community College \\ Di Xu \\ University of California, Irvine
}

\begin{abstract}
With the rapid growth of online learning at community colleges and the low course completion and performance associated with it, there has been increasing need to identify effective ways to address the challenges in online teaching and learning at this setting. Based on open-ended survey responses from 105 instructors and 365 students from multiple community colleges in a state, this study examined instructors' and students' perceptions of effective and ineffective instructional practices and changes needed in online coursework. By combining structural topic modelling techniques with human coding, we identified instructional practices that were perceived by both instructors and students as effective in supporting online learning as well as ineffective and needing improvement. Moreover, we identified a handful of misalignments between instructors and students in their perceptions of online teaching, including course workload and effective ways to communicate.
\end{abstract}

Keywords: online instruction, community college, instructor perception, student perception

Li, Q., Zhou, X., Bostian, B., Xu, D. (2021). How can we improve online learning at community colleges? Voices from online instructors and students. Online Learning, 25(3), 157-190. doi:10.24059/olj.v25i3.2362 
Community colleges provide a key point of access to postsecondary education for millions of low-income and minority students. Yet, community colleges face many challenges, including limited space, faculty shortages, and large proportions of students who hold jobs while enrolled in college and therefore may find it difficult to attend on-campus courses (Carnevale et al., 2015; Ives, 2006). These circumstances provide a context in which distance learning can thrive. Indeed, almost one-third of community college students attempted at least one course online in 2016; among these "ever online students," $40 \%$ took an entirely online curriculum (Xu $\& \mathrm{Xu}, 2019)$. Despite the high hopes for online learning to expand educational opportunities for community college students, existing studies have consistently identified high midsemester withdrawal rates and low course performance among online courses offered at community colleges (e.g., Hart et al., 2018; Xu \& Jaggars, 2013). Even more concerning is the fact that students from disadvantaged backgrounds, such as minority, low-income, academically underprepared students, and student parents, are subject to greater online performance decrements (Fendler et al., 2018; Johnson \& Mejia, 2014; Xu \& Jaggars, 2014; Wladis et al., 2016).

A growing effort has been directed to identify effective instructional practices that can better support online learning from both instructors' and students' perspectives (e.g., Bolliger \& Martin, 2018; Delen \& Liew, 2016; Jackson et al., 2010; Johnson \& Davies, 2014). Yet, most of these studies were conducted at four-year institutions, and the findings may not be generalized to community colleges due to the distinct populations the two sectors serve (e.g., Fike \& Fike, 2008; Xu et al., 2019). Due to open-door admission policies, community colleges disproportionately serve many racial minorities, low-income students, and non-traditional students. According to the report from Fry and Cilluffo (2019), the share of underrepresented minority students in community colleges in 2016 is $43 \%$ compared to $35 \%$ at public four-year universities and $29 \%$ at private four-year universities. Nearly $50 \%$ of community college students were from families below the lower-middle income threshold compared to $35 \%$ at public four-year and $27 \%$ at private four-year universities. In addition, around $40 \%$ of the students at community colleges tended to work full-time while enrolled compared to $21 \%$ at four-year universities (Brenden, Deil-Amen, Rios-Aguilar, 2015). Community college students also tend to be less academically prepared on average compared with four-year students (Fike \& Fike, 2008), and may need additional support to navigate an online course successfully. These differences in student populations imply that the specific challenges associated with online learning may differ between community college and four-year university students. Indeed, existing studies have consistently found large performance gaps between online and face-to-face courses at community colleges (e.g., Hart et al., 2018; Kozakowski, 2019; Xu \& Jaggars, 2014) compared with little to no performance decrements by course modality at four-year universities (e.g., Bowen et al., 2014; Joyce et al., 2015). Accordingly, it is unclear to what extent instructional practices perceived as effective among four-year faculty and students are also perceived as effective in promoting online learning at the community college setting.

Considering the rapid growth of online coursework at community colleges and the low course completion rates associated with online learning in this setting, it is critical to understand community college instructors' and students' perceptions of online instructional practices. To achieve this goal, we developed an anonymous open-ended survey and collected information systematically on instructors' and students' perceptions of effective and ineffective instructional practices and changes needed in online coursework across multiple community colleges in the 
North Carolina Community College System (NCCCS). By comparing instructors' and students' perceptions of effective and ineffective online instructional practices and how to improve online instruction, we intend to identify possible ways through which online instruction can be improved at community colleges.

This study builds on the existing literature and further contributes to it by collecting open-ended responses from both instructors and students on their perceptions regarding instructional practices in fully online courses from multiple institutions of a state community college system. Specifically, we address three research questions: what are community college instructors' and students' perceptions of (1) effective practices in online instruction, (2) ineffective practices in online instruction, and (3) critical changes necessary to improve online instruction?

\section{Instructional Practices to Facilitate Online Learning}

Several researchers have examined promising ways to support online instruction. These researchers seemed to agree that the challenges of online learning stem primarily from the increased need for self-regulation due to the absence of regular, structured, and physical class meetings (Broadbent \& Poon, 2015), the greater difficulties in achieving effective interpersonal interactions (Cox, 2006; Jaggars \& Xu, 2016), and the lack of easy access to student supports such as tutoring, counselling, and other services that are typically located on campus and are not available online (Destin, 2018; Schneider \& Clark, 2018). Based on teaching and learning theories both in general and in the specific setting of virtual environments, researchers have recommended several online instructional principles and specific practices that have the potential to address these challenges. For instance, Johnson and Davies (2014) proposed a list of instructional strategies to help students manage, evaluate, and adjust their learning processes, such as sending regular reminders and encouraging self-assessments. Similarly, Bolliger and Martin (2018) proposed 20 instructional strategies that have the potential to improve the quality of student-to-student and student-to-instructor interactions, such as having students introduce themselves to each other and providing students with detailed feedback on their assignments.

A growing number of studies attempted to examine instructor and student experiences and perceptions regarding online teaching practices. Primarily conducted at four-year universities, these studies found that instructors and students value strategies that keep students on track, such as providing checklists each week and sending reminders for upcoming deadlines (e.g., Bolliger \& Martin, 2018; Martin et al., 2018). Additionally, several studies found that both instructors and students highly rate practices that facilitate instructor-to-student and student-tostudent interactions, such as offering constructive feedback on students' progress and including icebreaker activities to allow students to introduce themselves to each other (e.g., Bolliger \& Martin, 2018; Bork \& Rucks-Ahidiana, 2013; Martin et al., 2018; Martin et al., 2020). For instance, Martin and colleagues (2020) surveyed 115 instructors at a southeastern university about their perceptions of the effectiveness of 12 facilitation strategies in online courses. The respondents rated timely responses to questions and feedback on assignments/projects the highest. These instructors also reported group projects and synchronous sessions to be helpful when asked about other effective strategies they used in their online classes. Interviews with online students and instructors further reveal that strategies for enhancing interpersonal interactions not only allow instructors to provide more timely academic support to students and allow students to learn from each other, but also help to create a sense of community and belonging in a virtual learning environment (Kear et al., 2014; Shieh et al., 2008). 
While studies conducted at four-year institutions provide important insights regarding possible strategies to better support online learning, it is unclear whether strategies perceived as effective in these studies may be applicable to the two-year setting (Fike \& Fike, 2008; Xu \& $\mathrm{Xu}, 2019$ ). For instance, while intensive online collaborative activities are generally well received by students in four-year universities (Bolliger \& Martin, 2018; Walker \& Kelly, 2007), these activities often involve strong time commitment from the students and therefore might be more challenging for community college students who tend to be less academically prepared and are more likely to enroll part-time.

A small but growing body of research has examined the perceptions and experiences of online instructors and students at community colleges (e.g., Cunningham, 2015; Jackson et al., 2010; Stanford-Bowers, 2008). For instance, Jackson and colleagues (2010) collected survey data on student perceptions of online courses from two community colleges and found that student course satisfaction was higher in classes where instructors provided more timely responses and engaging lectures and classroom activities. Cunningham (2015) surveyed 40 community college students about specific instructional practices for enhancing social presence in online courses and found that quick email responses from the instructor and collaborative group work opportunities played an important role. Similarly, Stanford-Bowers (2008) conducted group interviews with students, administrators, and faculty at one community college and elicited opinions on barriers to student persistence in online courses. Interestingly, the study identified disagreement in perceptions between the administrators/faculty and students: while students found the lack of adequate technical support, poor course design, and limited personal contact with instructors as the most important barriers, the administrators and faculty did not report these issues as concerns.

The incongruence between instructors and students identified in Stanford-Bowers's (2008) study regarding how to improve online learning highlights the importance of collecting opinions from both instructors and students. This may not only help collect effective instructional practices more comprehensively, but also pinpoint possible discrepancies between instructors and students regarding online teaching and learning. Such misalignment often contributes to non-optimal instruction and poor learning outcomes (Cox, 2009; Karp \& Bork, 2012) and may be exacerbated in online learning settings due to the lack of timely in-person communication (Bambara et al., 2009; Bork \& Rucks-Ahidiana, 2013; Stanford-Bowers, 2008). In addition, all the existing studies focus only on effective instructional practices in online learning. Yet, understanding instructional practices that are perceived as ineffective and/or needing changes, especially from students' perspectives, may also provide valuable insights into specific areas that require attention and improvement.

\section{Data Collection}

\section{Method}

This study was conducted during the spring term of the 2018-2019 academic year in the North Carolina Community College System (referred to as NCCCS hereafter), the third-largest community college system in the United States. NCCCS uses mainly Moodle and Blackboard to implement its online courses. Online course enrollments have risen steadily at NCCCS: from fall 2013 to fall 2017, the percentage of students who took at least one course online increased from $43 \%$ to $66 \%$. In a similar vein, $22 \%$ of the students who enrolled in the 2016-2017 academic year took online courses exclusively, which was up from 14\% in 2012-2013. Despite the steady increase in online enrollment, there has been a persistent performance gap between online and 
face-to-face courses: in fall 2015, the average course passing rate of online courses was $77 \%$, more than 10 percentage points lower than that of face-to-face courses.

In view of the persistent performance gaps, the NCCCS Excellence in Research and Analytics research team reached out to the official Distance Learning Administrator contacts for all the 58 North Carolina community colleges to help collect promising strategies in improving online learning experiences. These contacts were asked to further distribute a survey among faculty and students who had any online teaching and learning experiences at their individual colleges to reflect on effective and ineffective instructional practices that the respondent had experienced in online coursework and what changes were needed to improve online instruction. The detailed survey items and questions are presented in Table 1. It is important to note that the goal of this open-ended survey was not to understand how representative a particular practice had been used at NCCCS, nor to determine the views of the entire systems' students or faculty. Instead, it aimed to collect practices that are promising in improving online teaching and learning. Accordingly, most of the colleges relied on a convenience sample in collecting responses from online instructors and students.

\section{Table 1}

Survey Questions for Instructor and Students Respectively

Topic

\section{Questions asked}

To instructor

To student

$\begin{array}{ll}\text { Effective } & \text { In your online classes, or those you manage or } \\ \text { instructional } & \text { support, please describe any specific strategies } \\ \text { practices } & \text { that you have used, or helped others to use, that } \\ & \text { have produced consistent success in terms of } \\ & \text { higher course grades, course success rates, or } \\ & \text { persistence to the end of the course. }\end{array}$

Ineffective instructional practices

Changes necessary to improve online teaching and learning
In your online classes, or those you manage or support, what specific strategies have you used, or helped others to use, that have failed to produce consistent success or even reduced success in terms of lower course grades, course success rates, or persistence to the end of the course?

What kind of more general change do you think could significantly increase student success in online courses?
Please describe one or two things that instructors do in online courses that really help you learn, complete the courses, and get a good grade. Why do you think these things help you?

Please describe one or two things that instructors do or don't do in online courses that really prevent you from learning, cause you to withdraw, or get a bad grade.

If you could change one or two things about online courses that would help you to be more successful than you are now, what would those changes be? What would the changes look like? 
Twenty-seven colleges provided at least one response to either or both the faculty and the student versions of the survey, with 19 colleges providing at least one faculty response and 18 colleges providing at least one student response. Student demographic for the 27 responding colleges is fairly similar to those of the 58 community colleges in the system in terms of gender, ethnicity, and student age. A total of 105 instructors and 365 students from the 27 community colleges in NCCCS completed the survey. Compared with the demographics of students at NCCCS, the survey sample tended to have higher proportions of female students, White students, and African American students, while lower proportions of Hispanic students. ${ }^{1}$

\section{Analytical Approach}

We combined machine learning with human coding to identify core themes in instructor and student responses. Specifically, we first used structural topic modeling (STM) (Roberts, et al., 2014) to develop the coding scheme from the open-ended survey responses in an objective way and then conducted independent human coding of the entire sets of responses based on the key themes identified through STM. Compared with traditional human coding of qualitative data, STM does not require the researcher to establish an ex-ante coding framework, but instead allows the main themes to emerge from the large number of open-ended responses by analyzing the co-occurrence of these words and identifying words that frequently occur together. Yet, STM is limited in its ability to effectively identify themes in short texts-like the data used in this study - since the algorithm is mainly based on word co-occurrence in the data, which is limited in short texts due to data sparsity (Qiang, et al., 2017). Hand-coding the responses based on the key themes that have been identified through STM can thus help systematically examine the validity of the coding scheme developed based on STM and refine the coding scheme using human knowledge. Below, we outline the steps taken in our two-stage data analysis.

Development of coding schemes. In the first stage, we used STM to develop a coding scheme for each question and for instructor and student responses separately. The basic intuition behind STM is to group words based on the frequency of their co-occurrences in the responses. Based on the keywords in a word group identified by the algorithm, the researcher can then interpret the meaning of the words and the potential topic captured by these words. For instance, a group of words of "emails," "instructor," "communication," and "feedback" could be interpreted as a topic about "effective student-instructor communication." More specifically, the process of identifying key topics for each open-ended question involved three steps: (1) Conducting "stemming" to prepare the survey responses, which involved removing all punctuations, transforming the text to lowercase, and reducing words to their root form; (2) Setting the number of topics, where we estimated the model using a wide range of numbers of topics (e.g., from 2 to 30); and (3) Determining the optimal number of topics by balancing both the model fit and the interpretability of the results. In the third step, we first narrowed down the number of topics to a small range (e.g., from 2 to 8) based on the measures of held-out likelihood and semantic coherence. Then, two researchers coded the responses independently and determined the number of topics that made the most sense (e.g., 6 topics for instructor perceptions on effective instructional practices). After obtaining the keywords that emerged from

\footnotetext{
${ }^{1}$ The majority (77.84\%) of the student respondents were female, $58.8 \%$ of the students were White, $25.3 \%$ of them were African American, $6.3 \%$ of them were Hispanic, and $9.6 \%$ of them were other races or unknown. In contrast, among the students at NCCCS, $60 \%$ of them were female, $57 \%$ of them were White, $21 \%$ of them were African American, $12 \%$ of them were Hispanic, and $10 \%$ of them were other races or unknown.
} 
STM, researchers interpreted the collection of the words and identified the key themes based on the findings in the existing literature. Appendix A provides a detailed explanation regarding the steps through which we identified the key themes based on STM and Appendix B provides the model fit results for each survey question.

Human coding based on key themes. In the second stage, two assistants independently applied the themes that emerged from the STM to review and code all the survey responses. During this process, the research assistants paid special attention to themes that were not identified as a distinct theme based on the STM but aligned well with the existing literature on online teaching and learning. We added these themes to the coding scheme to complement the results from the machine learning algorithm with human knowledge. After each round of human coding, we calculated the kappa values for the agreement between the two assistants for each code, identified areas of disagreement, discussed the new codes added, and refined the coding schemes. We repeated this process three times until satisfactory levels of kappa statistics (0.70) were obtained (Landis \& Koch, 1977; McHugh, 2012). ${ }^{2}$ The final kappa statistics for all the codes ranged from 0.70 to 0.94 , with $73 \%$ of the codes having a kappa value higher than 0.8 (see Appendix C). Finally, a third researcher intervened to negotiate for a consensus where a disagreement occurred.

\section{Results}

A total of 36 themes were identified from instructors' and students' perceptions of effective and ineffective online instructional practices and required changes to improve online learning outcomes. Below we summarize the definition of these themes, sample responses for each theme, and the frequency of each theme. More detailed description of these themes and sample response is provided in Appendix D. ${ }^{3}$

\section{Effective Instructional Practices Instructor Perceptions}

(i) Regular announcements and reminders. The most frequently mentioned effective instructional practice, which appeared in nearly $30 \%$ of all instructor responses, is using regular announcements and reminders to give students clear guidance about what they need to do in the upcoming week and to remind them of upcoming assignments and exams. In addition to keeping students on track, instructors perceived regular announcements and reminders as an important channel of instructor-to-student communication, which demonstrated instructor presence in the course. For example, one instructor noted: "I communicate with my students three times per week. Weekly I post the announcements of assignments due. On the assignment due date, I send

\footnotetext{
${ }^{2}$ The kappa result can be interpreted as follows: values $\leq 0$ as indicating no agreement and $0.01-0.20$ as none to slight, $0.21-0.40$ as fair, $0.41-0.60$ as moderate, $0.61-0.80$ as substantial, and $0.81-1.00$ as almost perfect agreement.

${ }^{3}$ It is important to note that a theme that was reported by only a small number of survey respondents does not necessarily mean that these practices are not important due to two reasons. First, the survey did not urge respondents to provide an extensive list of instructional practices. In addition, since this study is not intended to be a representative study, the fact that some practices that were less frequently mentioned by the survey respondents does not mean that these practices are also less important for other instructors and students in the system. Since the goals of this study is to identify any themes that are worth considering in improving online teaching and learning, we decided to retain all the themes that emerged from the data (including those with small numbers of responses). That said, in discussing the implications from these findings in the discussion section, we intentionally avoid making claims or pedagogical recommendations based on a particular theme with few responses; instead, we focus on patterns of results that are shared across multiple themes or themes mentioned by at least $10 \%$ of the respondents in our sample.
} 
a reminder to the students who have not submitted their work for the week." In a similar vein, another instructor noted: "I periodically create video announcements with myself in them, so students get a sense of my presence in the class."

(ii) Varied materials and diversified media in content delivery. More than $25 \%$ of the online instructors found delivering course content using varied instructional materials and diversified media to be effective. Several instructors emphasized the use of visual presentations, particularly using lecture videos in addition to texts to enhance student learning. For example, several instructors said that they usually produced short videos that "introduce the material we will cover," "tie into the course topic," "explain more complicated concepts," or provide " how to' videos for assignments."

(iii) Proactive outreach with timely support. More than $20 \%$ of the instructors reported that they reached out to students who seemed to be struggling and gave them timely encouragement and guidance on their learning. These instructors indicated that such proactive outreach would motivate students who were fulfilling the expectations of the course and provide encouragement and timely support to students who were not. For example, one instructor mentioned: "If a student does poorly on an assignment early in the semester, I reach out individually and provide suggestions on how to improve next time, such as study strategies, proofreading more carefully, and taking advantage of multiple attempts. Then I give words of encouragement, like 'Hang in there, I know you can do this!'”

(iv) Timely response. Around $20 \%$ of the online instructors mentioned it was critical to respond to students' emails, discussion forum posts, and text messages promptly so that students felt the instructor was approachable and responsive. One instructor said: "I also respond to student emails throughout the day every day to ensure their questions are answered promptly and they feel heard."

(v) Quality feedback on assignments. Around $12 \%$ of the instructors suggested that quality feedback on assignments was essential to help students improve their performance. According to these instructors, the feedback should go beyond the numeric/letter grades and include personalized compliments of what students have done and constructive criticism. One instructor noted that he/she would always "highlight the things students have done well before delving into the areas for improvement" to "enable self-efficacy" and keep "a positive atmosphere." Another instructor focused on providing "detailed feedback for any loss of points on an assignment."

(vi) Offering discussion forum activities. Approximately $11 \%$ of the instructors indicated that discussion forum activities that involved student interaction had the potential to enhance learning from and social interactions with peers. Some instructors mentioned that they had "a weekly open forum so that students can discuss any issues they may have had with the chapter or with the assignments," "required discussion board where students help each other complete assignments," or "a fun icebreaker activity" on the discussion board.

\section{Student Perceptions}

Six themes were identified for students' perceptions of effective instructional practices.

(i) Varied materials and diversified media in content delivery. Close to $30 \%$ of the students appreciated when instructors used a variety of media and varied materials to deliver course content. They also appreciated when students were provided with multiple media to receive the same information, which allowed them to choose their preferred way of accessing the information. For example, one student found it helpful when instructors provided "multiple 
views of learning. For example, having videos, PowerPoint, readings etc. Not everyone learns the same way so having multiple teaching styles included helps."

(ii) Clear expectations on assignments. Around $20 \%$ of the students pointed out that it was critical for instructors to clarify their expectations on assignments. Students particularly appreciated specific guidance, clear evaluation criteria, and concrete examples that they could draw on to meet these expectations. One student mentioned: "Not all but most of my instructors give details on what they want in an assignment. Sometimes it can be misleading to students and [students] completed in a different way but not the way the instructor had wanted." Another student found "having easy to follow and descriptive instructions as well as samples greatly helps to complete assignments correctly."

(iii) Timely response. More than $15 \%$ of the students appreciated when instructors provided timely responses to their emails and discussion forum posts. Consistent with the comments from instructors, students reported that timely responses helped them get quick answers when they had questions and allowed them to move forward instead of lingering on the questions. One student noted: "When they respond to their email in a timely manner. This helps because I can get the assignment done without waiting too long."

(iv) Regular announcements and reminders. Close to $10 \%$ of the students suggested that regular announcements and reminders sent by instructors helped them stay on track. One student reported: "My biology teacher sends updates about assignments which helps me to stay on track in my class."

(v) Quality feedback on assignments. About 7\% of the students indicated that they benefit from the quality feedback from instructors. Feedback on assignments early on in a term helped students understand instructors' expectations and specific ways to improve their performance in future assignments. One student noted: "the thing that helps me the most is when they comment on the work I have done. It helps me to understand what they are looking for."

(vi) Explaining course content with concrete examples. Approximately $6 \%$ students suggested that it helped them to grasp the material when instructors provided concrete examples to explain the concepts, skills, and/or processes to be learned. One student mentioned, "[The instructor] explains what we are doing and gives an example of the concept in his life. This helps me understand the concepts better."

\section{Ineffective Instructional Practices} Instructor Perceptions

Four themes were identified from instructors' responses regarding ineffective instructional practices. Interestingly, three out of the four themes are about instructional practices that involve social interactions.

(i) Poor attendance in synchronous class meetings. Around $25 \%$ of the instructors found synchronous class meetings (e.g., video conferences and virtual office hours) ineffective due to low attendance rates. One instructor reported that most students did not attend synchronous meetings and preferred asynchronous communications: "I have attempted many attempts at synchronous meetings. We have made this a very easy process for our students, but most students do not prefer to meet synchronously. Most of our students live in an asynchronous world where they would rather text than make a phone call."

(ii) Lack of high-quality engagement in the discussion forum. More than $20 \%$ of the instructors suggested that discussion forum activities failed to achieve high-quality interactions as intended, especially student-student interactions. Instructors noted that students rarely took the initiative to respond to each other, even when responses were required. One instructor 
mentioned: "If I do not require that students respond to a discussion post a day or two after posting their own response, they never go back and read the thoughts of others." Another instructor reported: "I require peer feedback on discussion boards. However, some students regularly wait until the last day to post and never respond to a peer."

(iii) Unsuccessful group projects. More than $10 \%$ of the instructors found that group projects were not successful. They pointed out that this might be partially due to the greater challenges associated with effective collaboration in an online setting. One instructor reported: "I tried a collaborative Wiki page as a weekly assignment, but about half the groups seemed to have trouble figuring out how to collaborate."

(iv) Problems surrounding deadlines. Approximately $7 \%$ of the instructors reported that students had difficulties with following deadlines, especially when the deadlines were set in an inconsistent way across assignments. Some instructors specifically indicated that allowing extensions for assignments might result in students abusing the policy and falling behind.

\section{Student Perceptions}

Four themes emerged from students' responses to ineffective instructional practices that undermined their online learning.

(i) Insufficient instructor communication and engagement. Around $25 \%$ of the students indicated that there was limited instructor communication and engagement in online courses, leading to insufficient support for students to understand the course content and complete assignments. One student complained: "The majority of the instructors are not really involved in my online classes. If I am lucky, I might hear from them once or twice during the semester to remind me to do some assignment or take a test."

(ii) Unclear expectations on course assignments. Close to $25 \%$ of the students reported that they were confused and were not able to complete assignments appropriately due to a lack of clarification of instructor expectations and clear guidance on how an assignment should be completed. One student complained that instructors "sometimes forget to give examples to help understand the concept of the assignment and what exactly the instructor is looking for."

(iii) Unreasonable workload. More than $10 \%$ of the students reported unreasonable workload from their online courses, which impeded them from optimal learning gain. For example, one student noted: "I feel sometimes online courses are so jam-packed with busy work that I focus on getting assignments done and don't really retain the information." Interestingly, some students also expected online courses to have a lighter course load than face-to-face courses and were disappointed with unreduced demand. One student explained: "Instructors do not give a fair course load. A lot of us take online classes because we're older, work full time, have families and the course load is meant for kids who don't have much going on outside of school."

(iv) Insufficient feedback on assignments and assessments. Around $10 \%$ of the students reported that sometimes instructors did not provide sufficient feedback on assignments and/or assessments, giving students limited information on how to improve their performance in future assignments and assessments. In addition, among the responses mentioned lacking sufficient feedback, more than $60 \%$ of the student respondents mentioned the need for "timely feedback," specifically. For example, one student noted that instructors may "wait to the last minute to grade assignments and don't give feedback. This causes the students to work in the dark, not knowing if the assignment they completed was correct or not before they submit another assignment." Similarly, close to $15 \%$ of the feedback-related responses mentioned the 
lack of "detailed feedback". For example, one student reported that "the instructors that do not give specific explanations as to what you did wrong on an assignment are the worst."

\section{Changes Necessary to Improve Online Teaching and Learning}

\section{Instructor Perceptions}

Six themes were identified from instructors' responses about changes necessary to improve online teaching and learning.

(i) Improving instructor communication and engagement. The most common theme as reported by more than $25 \%$ of the instructors is that the instructors should make efforts to improve the level and quality of their communication with students and engagement in the course: "Instructor communication and presence in the class if the instructor doesn't attend the class why should the students?" Instructors perceived communication as fundamental to developing a positive instructor-student relationship, which in turn helps students feel connected to the course and strengthens their motivation to learn and succeed. Instructors highlighted specific ways how their communication with students could be improved, such as increasing the levels of communication (e.g., "A higher level of faculty-student communication") and humanizing instructor-student interaction (e.g., "I think it is very important to make personal contact with students" and "instructors who are open to letting their students know them as people. Instructors who are humorous).

(ii) Clarifying expectations on online learning. Nearly $20 \%$ of the instructors suggested that students tended to underestimate the workload in online courses and have insufficient skills, such as the ability to manage time wisely and to keep track of progress on course assignments that are critical to successful online learning. Thus, it is important to clarify course expectations and communicate explicitly the challenges associated with online learning early on. For example, one instructor stated that it would be helpful to clarify that "better time management skills" were needed since "students think that online classes are easier just because they don't have to be in a classroom but actually it's important that students understand the time commitment and focus needed."

(iii) Delivering content using varied materials and diversified media. Around $10 \%$ of the instructors mentioned that they would like to use more diversified media in content delivery (e.g., "I think students need to have video examples available not just a textbook") and bring in additional useful and varied materials into the instruction (e.g., "provide a variety of content and assessments"). One instructor said: "I have provided my students with multiple resources in order to make them successful. I am continuing to add anything I am made aware of in order to help my students. I am finding that a number of students take advantage."

(iv) Providing timely response. Nearly $5 \%$ of the instructors mentioned that they would like to do a better job providing timely responses to students' needs and questions. They indicated that students were more likely to actively seek help from the instructor and develop a personal connection with the instructor when they felt that the instructor was approachable and responsive. One instructor mentioned: "Respond timely to students when they have a technical problem, or questions. If it takes days to get a response, or students don't get a response at all, it defeats the learning experience, and conveys a lack of caring to students."

(v) Improving feedback on assignments and assessments. A handful of instructors (3\%) reported that they would like to try to improve both the quantity (e.g., "regular feedback from instructors" and "immediate weekly feedback") and quality of the feedback provided to students (e.g., "detailed feedback on assignments"). For instance, one instructor emphasized the need to "provide instructive feedback anytime a student does not receive a perfect score." 
(vi) Improving feedback on student progress. In addition to providing better feedback on assignments, several instructors (around 3\%) suggested that they would like to better monitor and provide feedback on students' overall progress in a course. One instructor mentioned: "More automatic monitoring and feedback of student progress, starting early in the term with attendance and completion of early assignments."

\section{Student Perceptions}

Six themes were identified from student responses about changes necessary to improve online teaching and learning. It is worth noting that more than $20 \%$ of the students reported that no change in online instruction was needed. ${ }^{4}$ As a result, themes identified under this question tend to receive a smaller number of mentioning by respondents.

(i) Delivering content using varied materials and diversified media. The change most frequently suggested by students (around 10\%) is to use diversified content delivery media, particularly audio or videos with instructor presence, and to provide varied course materials, such as multiple examples of the implication of the course content in different scenarios. One student mentioned: "I like when teachers video themselves explaining the lessons. When the instructor gives verbal information about the subject it really helps, especially for those who are audible learners."

(ii) Setting up deadlines in more reasonable ways. Approximately $7 \%$ of the students reported that instructors should set up the due dates in a more reasonable way. Some students suggested setting up a clear schedule for assignments early in the course so that the students could plan their time. One student mentioned: "More professors to post due dates for assignments as early as possible for students who may need to work ahead for whatever reason."

(iii) Improving discussion board activities. Nearly $5 \%$ of the students reported that, while they believed discussion board activities could be beneficial, the current discussion forum activities needed to be substantially improved. On one hand, students recognized discussion forum to be a valuable way to "share information," "get in touch and assist each other," and "express concerns" and would like to "have more interactive assignments on the discussion board." On the other hand, students felt that the current discussion board activities were "just busy work" and did not generate meaningful and productive conversations. One student complained that "students are typically forced to respond to a certain amount of people which ends up not being a productive discussion. There needs to be more back and forth discussion about intriguing topics."

(iv) Sending regular announcements and reminders. About $4 \%$ of the students would like their instructors to send announcements and reminders more frequently, such as "email[ing] students regularly about due dates."

(v) Providing timely response. Around $2 \%$ of the students suggested that more timely responses to their needs and questions were needed. Some students mentioned that it would be helpful if the instructors made themselves more accessible and were able to answer emails or discussion forum posts in a timely manner. One student noted: "I need professors to respond to their emails in a timely manner. Sometimes their help is extremely needed when taking an online course."

(vi) Improving feedback on assignments and assessments. Nearly $1 \%$ of the students suggested that they would like to receive better feedback on assignments. Some students mentioned that feedback on assignments should go beyond grades to help students know why

\footnotetext{
${ }^{4}$ Among the students who reported "no changes needed," most of them did not report any ineffective practices either. Others reported practices that they found ineffective but could not think of a specific way to improve it.
} 
their answers were incorrect and how to correct them. One student complained: "When I get a question wrong, I would like a complete answer on where the answer can be found in the text and why it is wrong."

\section{Discussion and Conclusion Summary of Key Findings and Relevance in The Existing Literature}

We identified several instructional practices that both instructors and students found to be effective in supporting online learning. These practices can be grouped into one of two categories. The first category includes practices that aim at facilitating instructor-student interaction, such as sending regular announcements and reminders and responding to students' questions in a timely manner. These practices have also been commonly cited as important ways to improve student engagement in the existing online learning literature (e.g., Bolliger \& Martin, 2018; Jackson et al., 2010), as they help students to establish personal connections with the course instructor, which in turn helps students feel connected to the course and strengthens their motivation to learn and succeed (Xu et al., 2020). The second category involves practices that have the potential to improve student-content interaction, such as providing varied materials and using diversified media in content delivery. This aligns well with the research in multimedia learning that suggests multimedia help to strengthen retention of information by providing students with both verbal and visual representations of the information (Mayer \& Moreno, 1998; Moreno \& Mayer, 1999). Additionally, providing students with diversified media for the same content allows students to choose their preferred way of accessing the information, and is thus more responsive to the needs and interests of diverse groups of students (Martin \& Bolliger, 2018). Interestingly, some of these "effective practices" are also mentioned in respondents' comments on "changes necessary to improve online teaching and learning," such as the need of varied materials and diversified media in content delivery. This implies that despite the agreement on the potential of these practices in improving online success, there may be important hurdles standing in the way of implementing these strategies in an optimal way.

Students and instructors reached less consensus on "ineffective strategies." Yet, one key theme that both instructors and students agreed on is discussion board activities. Specifically, discussion forum activity was reported as being ineffective in achieving high-quality studentstudent interaction by around $20 \%$ of the instructors and was on the top of the list of instructional practices that needed to be improved by both students and instructors. This result aligns with prior findings that student-student interaction was negatively associated with course completion in online courses at community colleges (e.g., Grandzol \& Grandzol, 2010) and adult students in online professional development programs tended to not value interpersonal interactions with peers (Rhode, 2009). Meanwhile, this finding contrasts with previous studies conducted at fouryear institutions where both instructors and students, especially undergraduates, viewed discussion board activities as effective and indispensable to facilitating interpersonal interactions in online learning (e.g., Bolliger \& Martin, 2018; Walker \& Kelly, 2007). Yet, this finding does not necessarily mean that student-student interactions are not as important at community colleges. Instead, it might be that it is more challenging to organize high-quality online student interaction, such as meaningful discussion forum activities in settings where a large proportion of students have other commitments outside school and are academically underprepared (Croxton, 2014).

Prior research conducted in community colleges documented misalignments between students and instructors in various perceptions, including students' responsibilities, instructor 
responsiveness, and specific ways instructors should consider improving student engagement (e.g., Bork \& Rucks-Ahidiana, 2013; Stanford-Bowers, 2008). Our results support this phenomenon and reveal two specific areas of misalignments. First, instructors and students diverged on what should be a reasonable workload for online students. While students expected online course to impose less coursework on students and adjust to the busy schedule of adult learners, instructors seemed to expect online students to exert equal levels of efforts, if not more. The consistent findings about the discrepancies between instructors and students in their perceptions of online learning may indicate that both instructors and students have misconceptions about the challenges of online learning and the responsibilities they need to assume when teaching/learning online (Bawa, 2016). Therefore, while a statement about the course workload required can be provided to alleviate potential misunderstanding, additional systematical professional development and online learning orientations may be needed to address the fundamental misconceptions about online learning (Bawa, 2016).

In addition, while both instructors and students valued student-instructor interactions, they differed in their preferred way of communication: while more than $25 \%$ of the instructors reported providing synchronous class meetings, students rarely took advantage of these opportunities. Instead, students generally preferred asynchronous interactions with the course instructor, such as through text messages and emails. This finding aligns with some of the existing literature that points out that students, especially adult learners, prefer asynchronous over synchronous tools as the former are more flexible to use for help-seeking, and induce less social anxiety (e.g., Li et al., 2011; Hsiao, 2012; Hollenbeck et al., 2011; Tello, 2007).

\section{Implications}

The findings from this study have several pedagogical and policy implications. First, we identified a list of instructional practices that were perceived as effective in supporting online learning by both instructors and students and can, therefore, be promoted widely among online course instructors. In spite of consistent evidence on the effectiveness of these instructional practices in the literature, our results indicate that some of these practices may not have been well implemented in online courses at community colleges. Institutions may consider promoting these practices by incorporating them into online course evaluation rubrics, as well as professional development opportunities to guide instructors to apply them to their own instruction.

Second, the findings of the ineffective practices and the misalignment between instructors and students in online course workload highlight the importance of providing additional support to both online instructors and students. Specifically, to enable instructors to design and coordinate discussion forum activities in a more engaging way, it is important that instructors receive guidance and necessary support on the importance and techniques of deploying specific tools to facilitate interpersonal interactions and build a sense of community (Baran \& Correia, 2014; McKenna et al., 2019). In a similar vein, the literature on online learning has identified several ways to address misalignments between instructors and students in their perceptions of student/instructor responsibility, workload, and skills necessary for successful online learning (e.g., Bawa, 2016; Bork \& Rucks-Ahidiana, 2013; Stanford-Bowers, 2008). For students, online readiness assessments and systematic course orientation that outlines the recommended study behaviors and responsibilities expected of students at the beginning of a course could help students understand the challenges of online learning, an individual's readiness to learning online, and the skills necessary for successful learning in a virtual environment. Similarly, instructors may benefit from professional development activities that provide important 
information on the characteristics of students enrolled in online courses, the challenges these students typically face, and additional support that students need to succeed in online learning.

Finally, given the misalignment between instructors and students in their preferred way of communication, instructors will need to consider the strengths and weaknesses of different interaction tools and use them strategically to meet specific instructional needs. For instance, instructors may use asynchronous tools for daily communications, such as text messages to send students reminders and emails to answer students' questions. In the meantime, instructors may offer occasional synchronous meetings such as video conferences to strengthen student-instructor connection and promote social presence (Hrastinski, 2008; Moallem, 2015).

\section{Limitations and Future Research Direction}

This study has several limitations: First, it utilized a relatively small convenience sample. This is partly due to the low response rate associated with an open-ended survey, which requires greater efforts to answer the questions (Moser \& Kalton, 2017). Accordingly, findings from this study may not be representative of typical opinions of online instructors and students at NCCCS. Yet, open-ended surveys allow flexible responses from participants and is an especially useful exploratory tool for identifying themes that are not pre-determined by researchers. Future research can build on the list of instructional practices identified in our study to develop closeended questionnaires to systematically collect information from online instructors and students at a larger scale at community colleges. Additionally, our study validates the instructional practices only with student and faculty perceptions and opinions, rather than student performance outcomes. Thus, even for a practice that is deemed highly effective by both instructors and students, it is unclear whether it will indeed lead to higher student course success rates. Future studies are needed to evaluate the impacts of the perceived effective practices on student learning outcomes through rigorous research designs.

Here we present two examples of our ongoing efforts to demonstrate how findings from the current study could be used effectively to inform data collection that intends to capture instructional practices and their relationship to student outcomes in a more systematic way. First, drawing on the instructional practices nominated by online instructors and students in the current study, we developed a comprehensive close-ended survey that systematically collects information on college online instructors' use of instructional practices that are promising in engaging and supporting students in an online course. We administered the survey to online instructors at multiple community colleges and examined how reported frequencies of practices may cluster to form meaningful groups of instructors, as well as factors (e.g., instructor background characteristics) that are correlated with the implementation of these practices.

In addition, to explain how an online course could be designed to address the challenges of online learning, the second research project developed an online course quality rubric (Xu et al., 2020) to provide a systematic and descriptive benchmark for researchers and practitioners who are striving to develop a culture of high-quality college-level online courses. We used the rubric to observe one hundred online courses randomly selected from a large community college and link these observations to student course performance data to provide empirical link between specific instructional practices and student learning outcomes. Findings from the current study provide critical foundations for developing the survey instruments and the online rubric for the two ongoing quantitative projects described above. 


\section{Conclusion}

This study examines instructor and student perceptions of online instruction at community colleges to identify effective online instructional practices, issues with the current online instruction, and possible strategies for future improvement. Despite the limitations and caveats mentioned above, this study sheds light on important ways to improve online instruction in community colleges by identifying specific practices that either offer promising ways to support or could potentially impede teaching and learning in a virtual environment. Our results also reveal misalignments between online students and instructors in their expectations of course workload and preferred ways of communication. Taken together, these findings highlight the importance of providing clear guidance to navigate the learning process and to improve interpersonal interactions and student engagement more intentionally and visibly in online courses. Finally, we illustrate specific ways how findings from this open-ended survey can be used to inform future development of closed-ended surveys or other data collection tools to capture the use of instructional practices and perceptions of these practices at scale. 


\section{References}

Baran, E., \& Correia, A. P. (2014). A professional development framework for online teaching. TechTrends: Linking Research and Practice to Improve Learning, 58(5), 95-101. https://doi.org/10.1007/s11528-014-0791-0

Bambara, C. S., Harbour, C. P., Davies, T. G., \& Athey, S. (2009). Delicate engagement: The lived experience of community college students enrolled in high-risk online courses. Community College Review, 36(3), 219-238. https://doi.org/10.1177/0091552108327187

Bawa, P. (2016). Retention in online courses: Exploring issues and solutions-A literature review. Sage Open, 6(1). https://doi.org/10.1177/2158244015621777

Bolliger, D. U., \& Martin, F. (2018). Instructor and student perceptions of online student engagement strategies. Distance Education, 39(4), 568-583. https://doi.org/10.1080/01587919.2018.1520041

Bork, R. H., \& Rucks-Ahidiana, Z. (2013). Role ambiguity in online courses: An analysis of student and instructor expectations [CCRC Working Paper No. 64]. Columbia University. https://doi.org/10.7916/D8C24TGV

Brenden, S., Deil-Amen, R., \& Rios-Aguilar, C. (2015). Anyone like me? Identity and social media among nontraditional-age community college students. bepress.

Broadbent, J., \& Poon, W. L. (2015). Self-regulated learning strategies \& academic achievement in online higher education learning environments: A systematic review. The Internet and Higher Education, 27, 1-13. https://doi.org/10.1016/j.iheduc.2015.04.007

Bowen, W. G., Chingos, M. M., Lack, K. A., \& Nygren, T. I. (2014). Interactive learning online at public universities: Evidence from a six-campus randomized trial. Journal of Policy Analysis and Management, 33(1), 94-111. https://doi.org/10.1002/pam.21728

Carnevale, A., Jayasundera, T., Repnikov, D., \& Gulish, A. (2015). State online college job market: ranking the states. Georgetown University Center on Education and the Workforce. https://eric.ed.gov/?id=ED558165

Cunningham, J. M. (2015). Mechanizing people and pedagogy: Establishing social presence in the online classroom. Online Learning, 19(3), 34-47. https://files.eric.ed.gov/fulltext/EJ1067482.pdf

Chen, Y., Yu, B., Zhang, X., \& Yu, Y. (2016, April). Topic modeling for evaluating students' reflective writing: A case study of pre-service teachers' journals. In Proceedings of the Sixth International Conference on Learning Analytics \& Knowledge (pp. 1-5). https://doi.org/10.1145/2883851.2883951 
Croxton, R. A. (2014). The role of interactivity in student satisfaction and persistence in online learning. Journal of Online Learning and Teaching, 10(2), 314-325.

https://jolt.merlot.org/vol10no2/croxton_0614.pdf

Cox, R. D. (2006). Virtual access. In T. Bailey \& V. S. Morest (Eds.), Defending the community college equity agenda. Johns Hopkins University Press.

Cox, R. D. (2009). The college fear factor. Harvard University Press.

Delen, E., \& Liew, J. (2016). The use of interactive environments to promote self-regulation in online learning: A literature review. European Journal of Contemporary Education, 15(1), 2433. https://www.learntechlib.org/p/194882/

Destin, M. (2018). Leveraging psychological factors: A necessary component to improving student outcomes. Third Way. https://www.thirdway.org/report/leveraging-psychologicalfactors-a-necessary-component-to-improving-student-outcomes

Fendler, R. J., Ruff, C., \& Shrikhande, M. M. (2018). No significant difference-Unless you are a jumper. Online Learning, 22(1), 39-60. https://files.eric.ed.gov/fulltext/EJ1179646.pdf

Fike, D. S., \& Fike, R. (2008). Predictors of first-year student retention in the community college. Community College Review, 36(2), 68-88. https://doi.org/10.1177/0091552108320222

Fry, R., \& Cilluffo, A. (2019). A rising share of undergraduates are from poor families, especially at less selective colleges. Pew Research Center.

https://vtechworks.lib.vt.edu/handle/10919/92670

Grandzol, C. J., \& Grandzol, J. R. (2010). Interaction in online courses: More is not always better. Online Journal of Distance Learning Administration, 13(2). https://www2.westga.edu/ distance/ojdla/summer132/Grandzol_Grandzol132.html

Hart, C. M. D., Friedmann, E., \& Hill, M. (2018). Online course-taking and student outcomes in California community colleges. Education Finance and Policy, 13(1), 42-71. https://doi.org/10.1162/edfp_a_00218

Hollenbeck, C. R., Mason, C. H., \& Song, J. H. (2011). Enhancing student learning in marketing courses: An exploration of fundamental principles for website platforms. Journal of Marketing Education, 33(2), 171-182. https://doi.org/10.1177/0273475311410850

Hrastinski, S. (2008). The potential of synchronous communication to enhance participation in online discussions: A case study of two e-learning courses. Information \& Management, 45(7), 499-506. https://doi.org/10.1016/j.im.2008.07.005

Hsiao, E. L. (2012). Synchronous and asynchronous communication in an online environment: Faculty experiences and perceptions. Quarterly Review of Distance Education, 13(1), 15-30. https://www.learntechlib.org/p/131977/ 
Ives, K. S. (2006). Community colleges and distance learning. Journal of Asynchronous Learning Networks, 10(3), 85-94. https://pdfs.semanticscholar.org/67b0/f42a69e3a64a5c070e8a94516f9f27457383.pdf

Jackson, L. C., Jones, S. J., \& Rodriguez, R. C. (2010). Faculty actions that result in student satisfaction in online courses. Journal of Asynchronous Learning Networks, 14(4), 78-96. https://files.eric.ed.gov/fulltext/EJ909918.pdf

Jaggars, S. S., \& Xu, D. (2016). How do online course design features influence student performance? Computers and Education, 95, 270-284.

https://doi.org/10.1016/j.compedu.2016.01.014

Johnson, G., \& Davies, S. (2014). Self-regulated learning in digital environments: Theory, research, praxis. British Journal of Research, 1(2), 1-14. http://hdl.handle.net/20.500.11937/45935

Johnson, H. P., \& Mejia, M. C. (2014). Online learning and student outcomes in California's community colleges. Public Policy Institute. https://www.luminafoundation.org/wpcontent/uploads/2017/08/r-514hjr.pdf

Joyce, T., Crockett, S., Jaeger, D. A., Altindag, O., \& O'Connell, S. D. (2015). Does classroom time matter? Economics of Education Review, 46, 64-77. https://doi.org/10.1016/j.econedurev.2015.02.007

Karp, M. M., \& Bork, R. H. (2012). "They never told me what to expect, so I didn't know what to do": Defining and clarifying the role of a community college student [CCRC Working Paper No. 47]. Columbia University. https://doi.org/10.7916/D8W09F54

Kear, K., Chetwynd, F., \& Jefferis, H. (2014). Social presence in online learning communities: The role of personal profiles. Research in Learning Technology, 22. https://doi.org/10.3402/rlt.v22.19710

Kozakowski, W. (2019). Moving the classroom to the computer lab: Can online learning with inperson support improve outcomes in community colleges? Economics of Education Review, 70, 159-172. https://doi.org/10.1016/j.econedurev.2019.03.004

Landis, J. R., \& Koch, G. G. (1977). The measurement of observer agreement for categorical data. Biometrics, 33(1), 159. https://doi.org/10.2307/2529310.

Li, L., Finley, J., Pitts, J., \& Guo, R. (2011). Which is a better choice for student-faculty interaction: synchronous or asynchronous communication? Journal of Technology Research, 2, 1. http://citeseerx.ist.psu.edu/viewdoc/download?doi=10.1.1.467.7214\&rep=rep1\&type=pdf 
Martin, F., Wang, C., \& Sadaf, A. (2018). Student perception of helpfulness of facilitation strategies that enhance instructor presence, connectedness, engagement and learning in online courses. The Internet and Higher Education, 37, 52-65.

https://doi.org/10.1016/j.iheduc.2018.01.003

Martin, F., Wang, C., \& Sadaf, A. (2020). Facilitation matters: Instructor perception of helpfulness of facilitation strategies in online courses. Online Learning, 24(1), 28-49. https://doi.org/10.24059/olj.v24i1.1980

Mayer, R. E., \& Moreno, R. (1998). A split-attention effect in multimedia learning: Evidence for dual processing systems in working memory. Journal of Educational Psychology, 90(2), 312320. https://doi.org/10.1037/0022-0663.90.2.312

McHugh, M. L. (2012). Interrater reliability: The kappa statistic. Biochemia Medica, 22(3), 276282. https://www.ncbi.nlm.nih.gov/pmc/articles/PMC3900052/

McKenna, K., Gebhardt, K., \& Altringer, L. (2019). Exploring community in discussion board activities. The Online Journal of Distance Education and e-Learning, 7(3), 185. https://tojdel.net/journals/tojdel/volumes/tojdel-volume07-i03.pdf\#page=43

Moallem, M. (2015). The impact of synchronous and asynchronous communication tools on learner self-regulation, social presence, immediacy, intimacy and satisfaction in collaborative online learning. The Online Journal of Distance Education and e-Learning, 3(3), 55-77. http://www.tojdel.net/journals/tojdel/volumes/tojdel-volume03-i03.pdf\#page=62

Moreno, R., \& Mayer, R. E. (1999). Cognitive principles of multimedia learning: The role of modality and contiguity. Journal of Educational Psychology, 91(2), 358368. https://doi.org/10.1037/0022-0663.91.2.358

Moser, C. A., \& Kalton, G. (2017). Survey methods in social investigation. Routledge.

Qiang, J., Chen, P., Wang, T., \& Wu, X. (2017, May). Topic modeling over short texts by incorporating word embeddings. In Pacific-Asia Conference on Knowledge Discovery and Data Mining (pp. 363-374). Springer, Cham. https://link.springer.com/chapter/10.1007/978-3-319$\underline{57529-2 \_29}$

Rhode, J. (2009). Interaction equivalency in self-paced online learning environments: An exploration of learner preferences. The International Review of Research in Open and Distributed Learning, 10(1). https://doi.org/10.19173/irrodl.v10i1.603

Roberts, M. E., Stewart, B. M., Tingley, D., Lucas, C., Leder-Luis, J., Gadarian, S. K., ... \& Rand, D. G. (2014). Structural topic models for open-ended survey responses. American Journal of Political Science, 58(4), 1064-1082. https://doi.org/10.1111/ajps.12103 
Schneider, M., \& Clark, K. (2018). Completion reforms that work: How leading colleges are improving the attainment of high-value degrees. Third Way.

https://www.thirdway.org/report/completion-reforms-that-work-how-leading-college-areimproving-the-attainment-of-high-value-degrees

Shieh, R. S., Gummer, E., \& Niess, M. (2008). The quality of a web-based course: Perspectives of the instructor and the students. TechTrends: Linking Research and Practice to Improve Learning, 52(6), 61. https://search.proquest.com/openview/89ec4562b11c35d18bbfb08f36af9f23/1?pqorigsite $=$ gscholar $\& \mathrm{cbl}=40581$

Stanford-Bowers, D. E. (2008). Persistence in online classes: A study of perceptions among community college stakeholders. Journal of Online Learning and Teaching, 4(1), 37-50. https://jolt.merlot.org/vol4no1/stanford-bowers0308.pdf

Tello, S. F. (2007). An analysis of student persistence in online education. International Journal of Information and Communication Technology Education, 3(3), 47-62. https://doi.org/10.4018/jicte.2007070105

Wladis, C., Conway, K. M., \& Hachey, A. C. (2016). Assessing readiness for online education-Research models for identifying students at risk. Online Learning, 20(3), 97-109. https://files.eric.ed.gov/fulltext/EJ1113351.pdf

Walker, C. E., \& Kelly, E. (2007). Online instruction: Student satisfaction, kudos, and pet peeves. Quarterly Review of Distance Education, 8(4), 309-319.

https://www.learntechlib.org/p/106669/

Xu, D., Li, Q., \& Zhou, X. (2020). Online course quality rubric: A tool box. Online Learning Research Center. https://par.nsf.gov/servlets/purl/10232436

Xu, D., \& Jaggars, S. S. (2013). The impact of online learning on students' course outcomes: Evidence from a large community and technical college system. Economics of Education Review, 37, 46-57. https://doi.org/10.1016/j.econedurev.2013.08.001

Xu, D., \& Jaggars, S. S. (2014). Performance gaps between online and face-to-face courses: differences across types of students and academic subject areas. The Journal of Higher Education, 85(5), 633-659. https://doi.org/10.1080/00221546.2014.11777343

Xu, D., Solanki, S., \& Harlow, A. (2019). Examining the relationship between 2-year college entry and baccalaureate aspirants' academic and labor market outcomes: Impacts, heterogeneity, and mechanisms. Research in Higher Education, 1-33. https://doi.org/10.1007/s11162-01909559-7

$\mathrm{Xu}, \mathrm{D} .$, \& Xu, Y. (2019). The promises and limits of online higher education: Understanding how distance education affects access, cost, and quality. American Enterprise Institute. http://hdl.voced.edu.au/10707/505263 


\section{Appendix A}

Open-ended data can provide valuable information through direct views into a respondent's thinking; yet many researchers and practitioners are reluctant to use open-ended surveys as they are more difficult to analyze than closed-surveys (Roberts et al., 2014). A major challenge with open-ended responses is that the analysis of text data requires the researchers to define the dimensions on which the data should be coded based on prior knowledge of the topic and theoretical expectations (Schuman \& Presser 1996). Although originating from computer science, structural topic modeling (STM) has been increasingly used in educational research as a powerful tool to identify key themes in educational text data, such as open-ended survey responses, discussion forum posts, and reflective writings (e.g., Chen, Yu, Zhang, \& Yu, 2016).

STM is applied to develop a coding scheme for each question and for instructor and student responses separately. The basic intuition behind STM is to group words based on the frequency of and their co-occurrences in the responses. Based on the keywords in a word group identified by the algorithm, the researcher can then interpret the meaning of the words and the potential topic captured by these words. More specifically, the process of identifying key topics for each open-ended question involves three steps.

(1) First, before we ran the STM, we conducted standard pre-processing called "stemming" to prepare the survey responses for each open-ended question for analysis. This involves removing all punctuations, transforming the text to lower case, and reducing words to their root form (e.g., removing tense and reducing "communicating" to "communicate").

(2) As an unsupervised method, STM requires setting the number of topics before running the model. The optimal number of topics needs to balance model fit and substantive interpretation. The recommended approach in the literature is to re-estimate the model multiple times with different pre-set numbers of topics and compare the topics that emerged from each estimation (e.g., Chen, et al., 2016). For each open-ended question, we therefore estimated the model using a wide range of numbers of topics from 2 to 30 .

(3) We then compared the results of each model and determined the optimal number of topics by balancing both the model fit and the interpretability of the results.

(a) We first narrowed down to a smaller range of numbers of topics that yielded similar and relatively better model fit based on two commonly used indicators of model fitthe held-out likelihood and the semantic coherence-of these models (more details are presented in Appendix B). For instance, for instructor perceptions of effective instructional practices, we chose to narrow down and focus on results using $\mathrm{K}$ equaling to 2 to 8 , which yield better model fit based on the two indicators (Appendix B Figure 1).

(b) Based on the numbers of topics chosen, STM generates several topics from the raw data and reports keywords and example responses associated with each topic. Considering that coding the topics into themes based on the word profiles requires human interpretation and decisions, two researchers coded the themes for the word profiles within each coding set independently and cross-validated our theme labels. Most of the themes were consistent regardless of the number of distinct topics pre-set by the researcher. In models with fewer topics, several of the themes identified in the more numerous coding schemes often ended with similar themes and therefore could be combined. 


\section{Appendix B}

For each survey question, we analyzed the responses using STM with a wide range of numbers of topics from 2 to 30, compared model fit of the results, and chose models with better fit to narrow the space of possible solutions. For each question, the model fit of the various solutions and the process and result of solution selection is presented below.

Instructor perceptions on effective instructional practices. Results of model fit for instructor perceptions on effective instructional practices are shown in Figure B1(a). As the number of topics increased from 2 to 30, the held-out likelihood fluctuated within a small range, and the semantic coherence increased from -85 to -75 first and then decreased gradually.

Therefore, we narrowed down the solutions to numbers of topics equaling 2 to 8 , which yielded a relatively similar and better model fit. Two researchers coded the responses independently and determined that six themes make the most sense.

Student perceptions on effective instructional practices. Results of model fit for student perceptions on effective instructional practices are shown in Figure B1(b). As the number of topics increased from 2 to 30, the held-out likelihood fluctuated within a small range from two to seven topics then fluctuated drastically; the semantic coherence decreased substantially from two to seven topics and then fluctuated within a small range. Therefore, we narrowed down the solutions to the numbers of topics equaling 2 to 7 , which and eventually led to six themes from student responses about effective instructional practices.

Instructor perceptions on ineffective instructional practices. Results of model fit for instructor perceptions on ineffective instructional practices are shown in Figure B2(a). Although large numbers of topics yield high semantic coherence (e.g., $K=25,27,29$, and 30), the large number of topics identified are not practically valuable for summarizing the key themes from a relatively small dataset $(\mathrm{N}=105)$. Looking at models with small number of topics, the held-out likelihood fluctuated within a small range from two to six topics; the semantic coherence decreased substantially from -120 to -140 from two to three topics, increased from -140 to around -120 from three to four topics, and then fluctuated within a small range from four to six topics. Therefore, we chose to focus on results using two, four, five, and six topics which yield relatively better though not the best model fit. Two researchers coded the responses independently and agreed on six themes.

Student perceptions on ineffective instructional practices. Results of model selection for student perceptions on ineffective instructional practices are shown in Figure B2(b). As the number of topics increased from 2 to 30, the held-out likelihood fluctuated within a small range from two to eight topics, while the semantic coherence decreased dramatically from four to five topics. Therefore, we narrowed down the solutions to the numbers of topics equaling 2 to 4 , which yield relatively better model fit, especially for semantic coherence. Two researchers agreed on four themes after human coding all the responses.

Instructor perceptions on changes necessary to improve online teaching and

learning. Results of model selection for instructor perceptions on changes necessary to improve online teaching and learning are shown in Figure B3(a). As the number of topics increased from 2 to 30 , the held-out likelihood fluctuated within a small range from two to six themes; the semantic coherence decreased first from two to six themes and then increased gradually. Therefore, we narrowed down the solutions to numbers of topics equaling 2 to 4 , which yielded a relatively better model fit and at the same time kept the results as interpretable as possible. After human coding all the topics generated by STM, two researchers agreed on four themes and after human coding all of the responses, another two themes were added. 
Student perceptions on changes necessary to improve online teaching and learning. Results of model selection for student perceptions on changes necessary to improve online teaching and learning are shown in Figure B3(b). As the number of topics increased from 2 to 30 , the held-out likelihood fluctuated within a small range from two to ten themes; the semantic coherence decreased first from two to four themes and then fluctuated within a small range from four to eight themes. We narrowed down the solutions to numbers of topics equaling 2 to 8 , which yielded a relatively better model fit for both held-out likelihood and semantic coherences. After human coding, six themes were identified from student responses about changes necessary to improve online teaching and learning. 
How Can We Improve Online Learning at Community Colleges?

Figure B1

Model Selection for Instructor (a) and Student (b) on Effective Instructional Practices
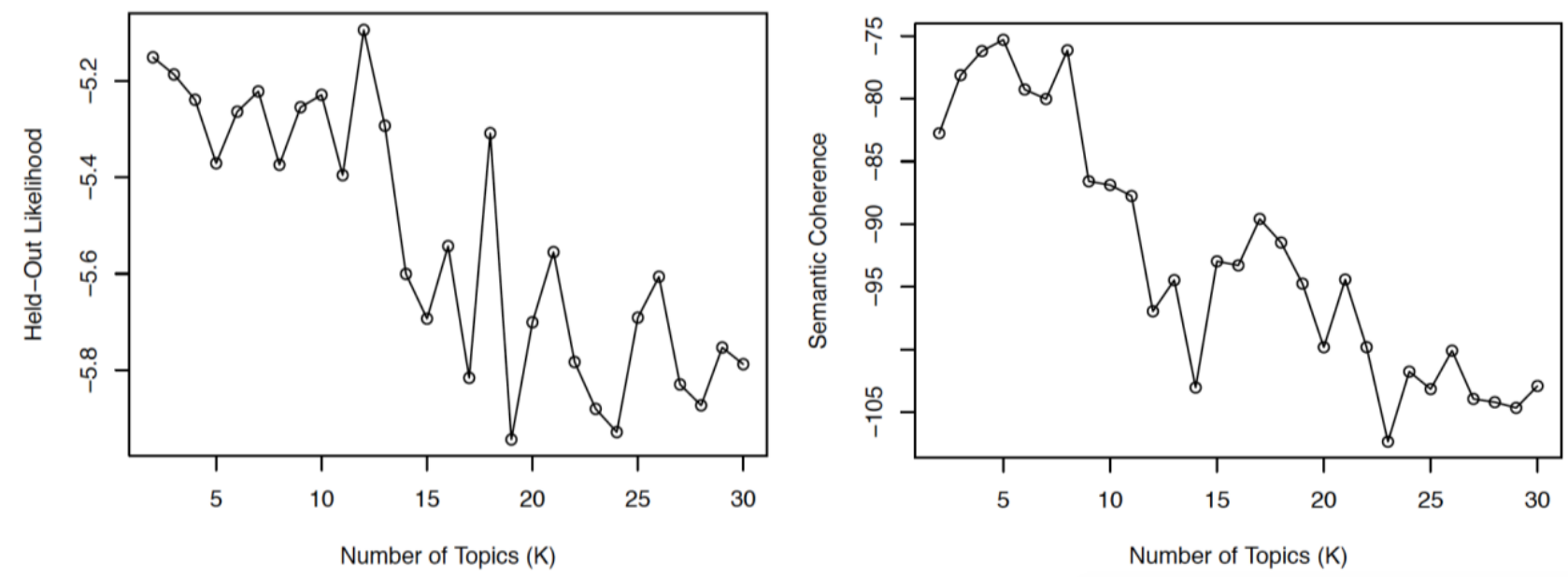

(a) Instructor Perceptions
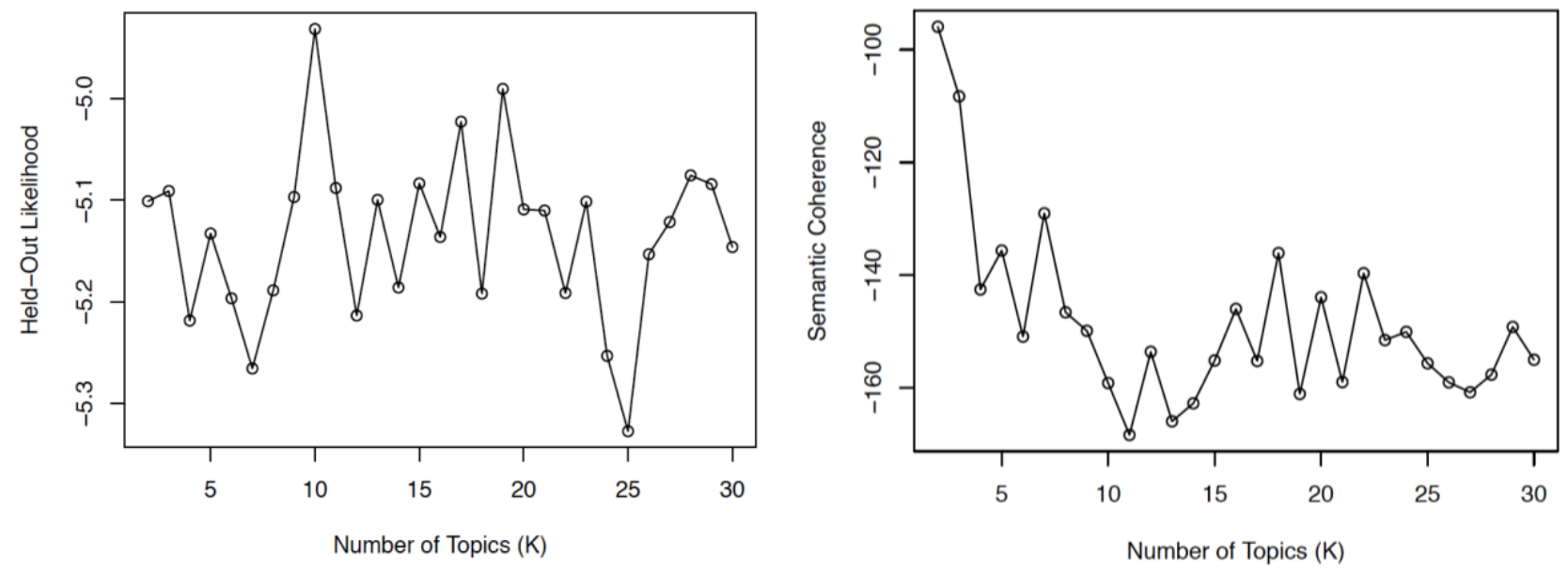

(b) Student Perceptions 
How Can We Improve Online Learning at Community Colleges?

Figure B2

Model Selection for Instructor (a) and Student (b) Perceptions on Ineffective Instructional

Practices
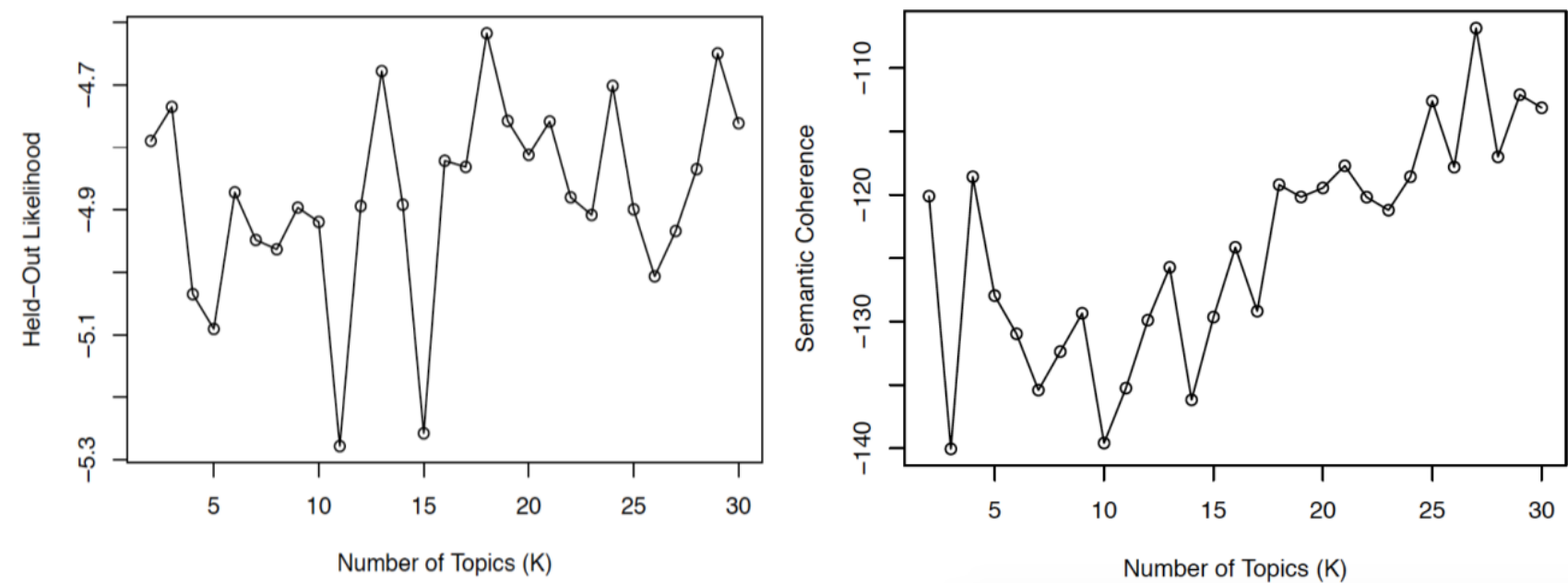

(a) Instructor Perceptions
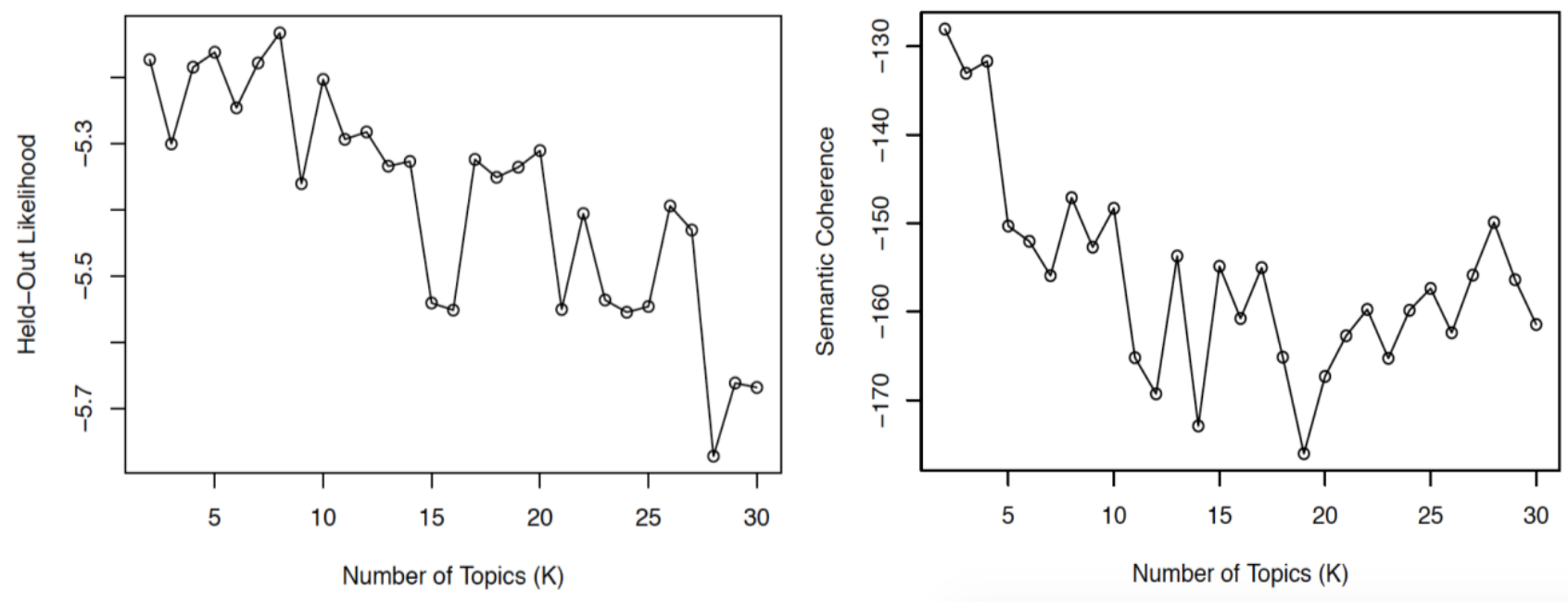

(b) Student Perceptions 
How Can We Improve Online Learning at Community Colleges?

Figure B3

Model Selection for Instructor (a) and Student (b) Perceptions on Changes Necessary to Improve Online Teaching and Learning
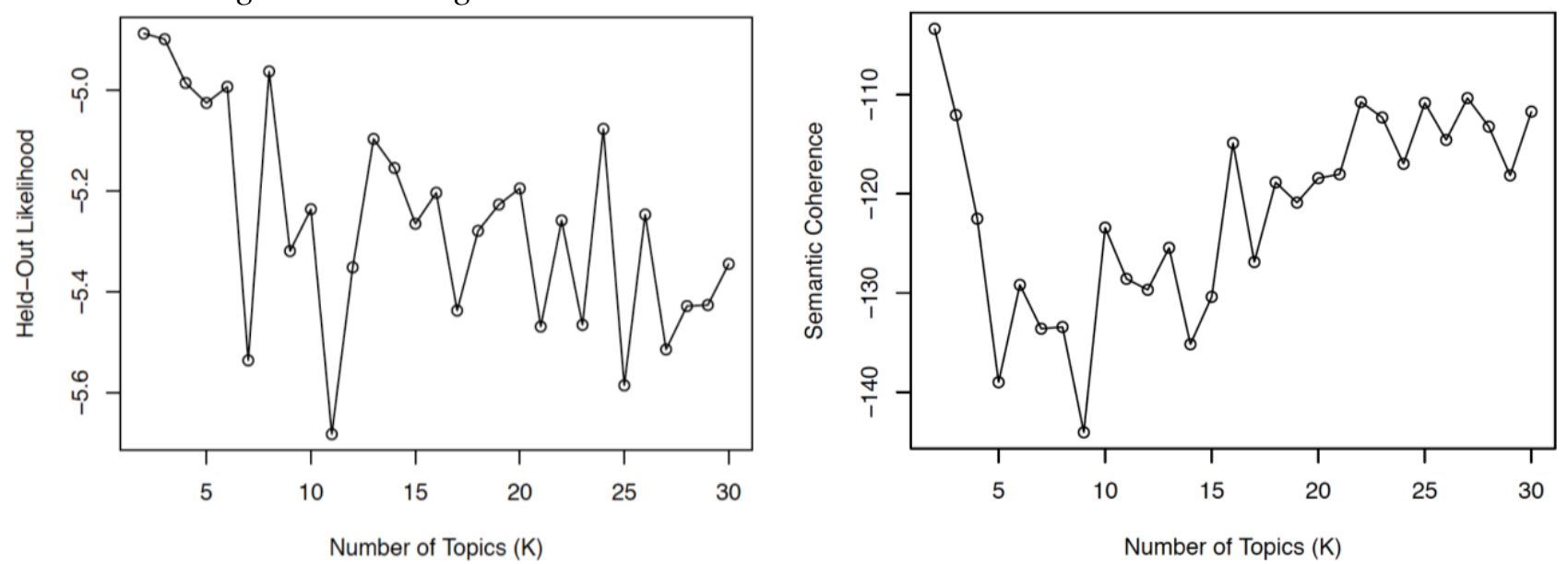

(a) Instructor Perceptions
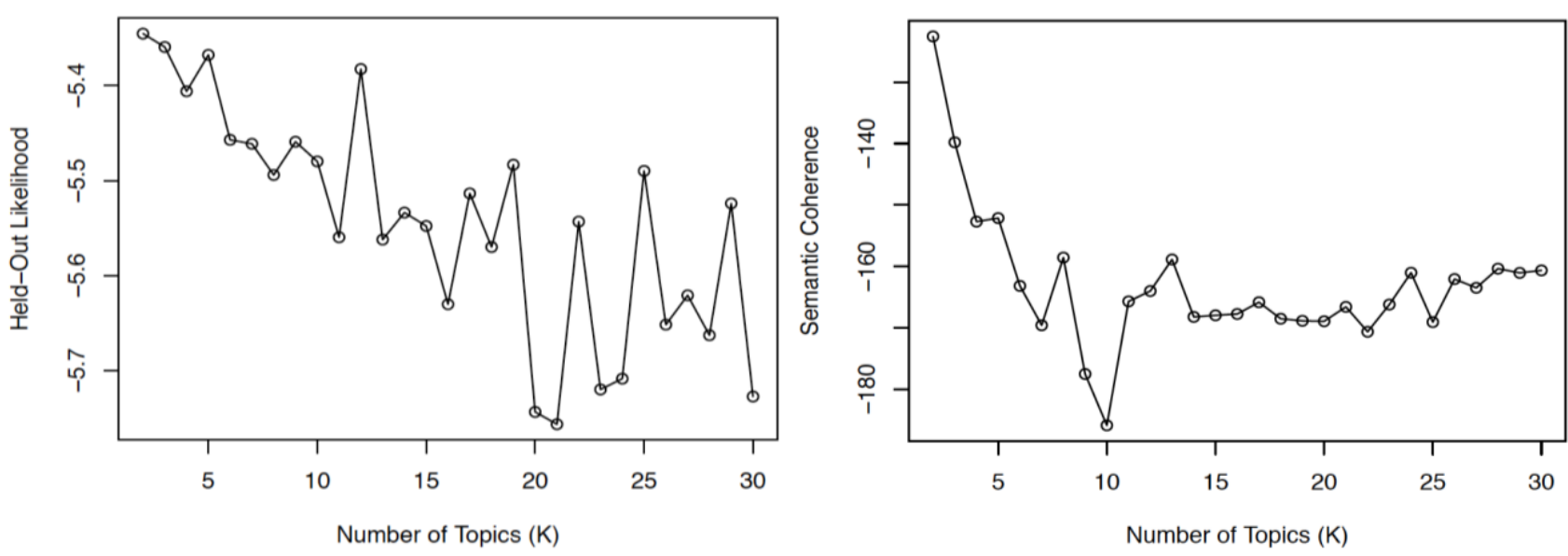

(b) Student Perceptions 
Table C1

\section{Appendix C}

Kappa Statistics for All the Codes

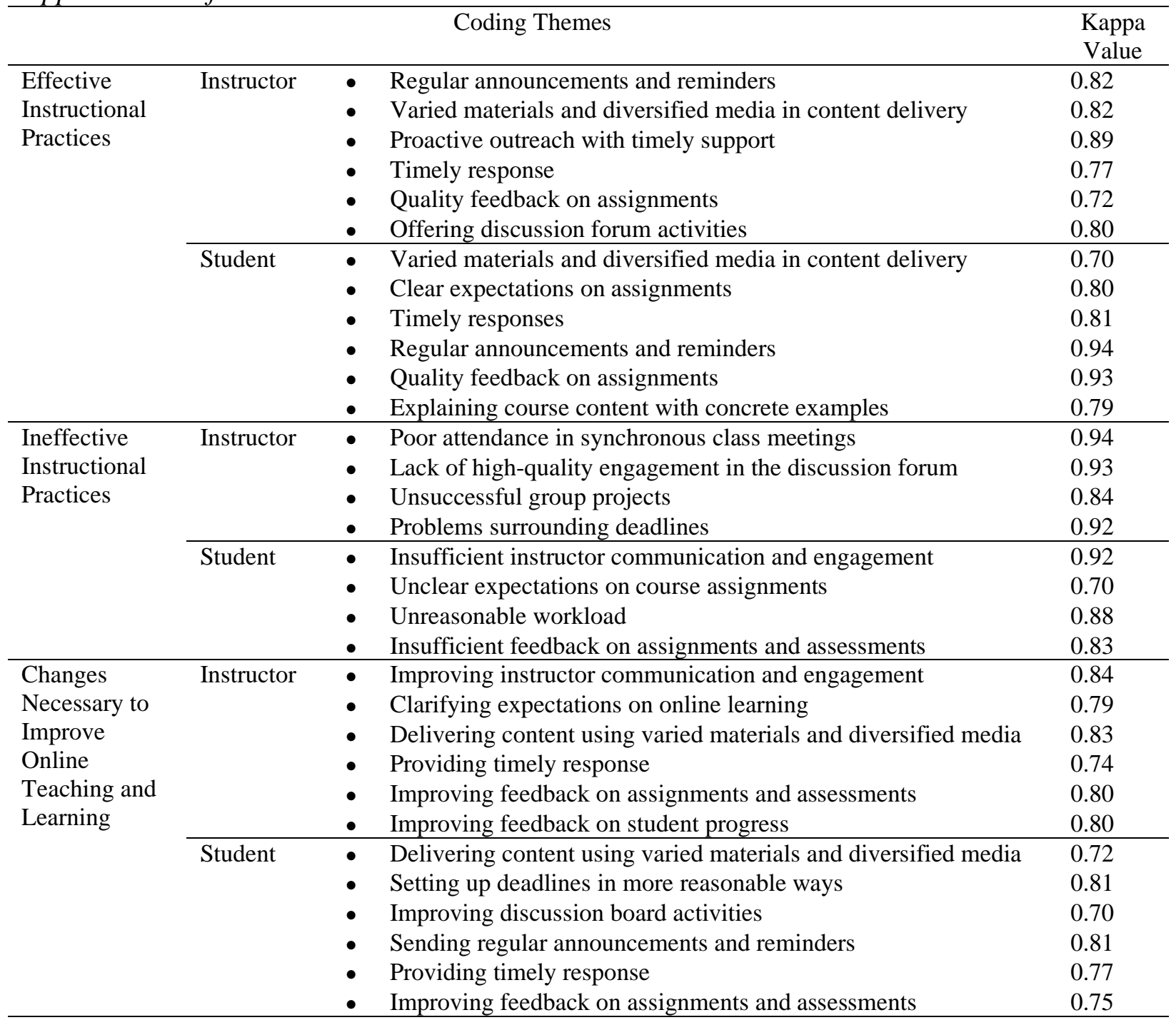


Table D1

\section{Appendix D}

Themes of Effective Instructional Practices from Instructor Survey

\begin{tabular}{|c|c|c|c|}
\hline Themes & Definition & Sample Responses & Frequency \\
\hline $\begin{array}{l}\text { Regular } \\
\text { announcements } \\
\text { and } \\
\text { reminders }\end{array}$ & $\begin{array}{l}\text { Instructors send } \\
\text { weekly } \\
\text { announcements or } \\
\text { reminders about the } \\
\text { due dates of } \\
\text { assignments or } \\
\text { upcoming exams. }\end{array}$ & $\begin{array}{l}\text { "I communicate with my students three times per week. } \\
\text { Weekly I post the announcements of assignments due. On } \\
\text { the assignment due date, I send a reminder to the students } \\
\text { who have not submitted their work for the week." } \\
\text { "I periodically create video announcements with myself in } \\
\text { them so students get a sense of my presence in the class." }\end{array}$ & $33 \%$ \\
\hline $\begin{array}{l}\text { Varied materials } \\
\text { and diversified } \\
\text { media in content } \\
\text { delivery }\end{array}$ & $\begin{array}{l}\text { Instructors use } \\
\text { multiple instructional } \\
\text { materials to illustrate } \\
\text { the course content }\end{array}$ & $\begin{array}{l}\text { "I produce a short video to introduce the material we will } \\
\text { cover and upload it on Monday." } \\
\text { "I create Camtasia videos to help explain more complicated } \\
\text { concepts." } \\
\text { "I post instructor videos for lectures and 'how to' videos for } \\
\text { other assignments." }\end{array}$ & $26 \%$ \\
\hline $\begin{array}{l}\text { Proactive } \\
\text { outreach with } \\
\text { timely support }\end{array}$ & $\begin{array}{l}\text { Instructors reach out } \\
\text { to students (e.g., } \\
\text { emailing students) } \\
\text { who seem to be } \\
\text { having problems } \\
\text { (e.g., students who } \\
\text { are falling behind or } \\
\text { miss assignments) } \\
\text { and provide timely } \\
\text { support }\end{array}$ & $\begin{array}{l}\text { "If a student does poorly on an assignment early in the } \\
\text { semester, I reach out individually and provide suggestions } \\
\text { on how to improve next time, such as study strategies, } \\
\text { proofreading more carefully, and taking advantage of } \\
\text { multiple attempts. Then I give words of encouragement, like } \\
\text { "Hang in there, I know you can do this!"" } \\
\text { "I frequently send out emails when students miss } \\
\text { assignments and encourage them to contact me with any } \\
\text { issues. I also REACHED OUT to students who were falling } \\
\text { behind, missed an assignment, or generally seemed to be } \\
\text { having problems." }\end{array}$ & $22 \%$ \\
\hline Timely response & $\begin{array}{l}\text { Instructors respond } \\
\text { to (or answering) } \\
\text { students' emails or } \\
\text { posts on discussion } \\
\text { board in a timely } \\
\text { manner and } \\
\text { frequently }\end{array}$ & $\begin{array}{l}\text { "I also respond to student emails throughout the day every } \\
\text { day to ensure their questions are answered promptly and } \\
\text { they feel heard." } \\
\text { I respond quickly to all emails and if students ask for an } \\
\text { extension on an assignment I try to be accommodating if I } \\
\text { can. I also let students text me or call me on my personal } \\
\text { cell phone. Some will text or call, but most students just } \\
\text { email me." }\end{array}$ & $20 \%$ \\
\hline $\begin{array}{l}\text { Quality } \\
\text { feedback on } \\
\text { assignments }\end{array}$ & $\begin{array}{l}\text { Instructors give } \\
\text { detailed/constructive } \\
\text { / clear feedback on } \\
\text { assignments }\end{array}$ & $\begin{array}{l}\text { "Always keeping a positive atmosphere. For example, I } \\
\text { always highlight the things students have done well before } \\
\text { delving into the areas for improvement. I want to enable } \\
\text { self-efficacy." } \\
\text { "Provide detailed feedback for any loss of points on an } \\
\text { assignment." }\end{array}$ & $12 \%$ \\
\hline $\begin{array}{l}\text { Offering } \\
\text { discussion board } \\
\text { activity }\end{array}$ & $\begin{array}{l}\text { Instructors } \\
\text { incorporate } \\
\text { discussion board } \\
\text { activities to } \\
\text { encourage student- } \\
\text { student interaction. }\end{array}$ & $\begin{array}{l}\text { "...I also have a weekly open forum so that students can discuss } \\
\text { any issues they may have had with the chapter or with the } \\
\text { assignments." } \\
\text { "Required discussion board where students help each other } \\
\text { complete assignments, meant to replicate the lab environment." } \\
\text { "...Students interact on discussion boards as well as start out the } \\
\text { semester with a fun icebreaker activity on discussion..." }\end{array}$ & $11 \%$ \\
\hline
\end{tabular}




\section{Table D2}

Themes of Effective Instructional Practices from Student Survey

\begin{tabular}{|c|c|c|c|}
\hline Themes & Definition & Sample Responses & Frequency \\
\hline $\begin{array}{l}\text { Varied materials } \\
\text { and diversified } \\
\text { media in content } \\
\text { delivery }\end{array}$ & $\begin{array}{l}\text { Instructors use multiple } \\
\text { instructional materials to } \\
\text { illustrate the course } \\
\text { content }\end{array}$ & $\begin{array}{l}\text { "Multiple views of learning. For example, } \\
\text { having videos, PowerPoint, readings etc. Not } \\
\text { everyone learns the same way so having } \\
\text { multiple teaching styles included helps." } \\
\text { "When the teacher includes a PowerPoint } \\
\text { with slides that contain specific examples } \\
\text { and shows how to get the correct answer, it } \\
\text { helps me understand not just the solution, but } \\
\text { how to achieve it." }\end{array}$ & $30 \%$ \\
\hline $\begin{array}{l}\text { Clear expectations } \\
\text { on assignments }\end{array}$ & $\begin{array}{l}\text { Instructors help students } \\
\text { understand what they are } \\
\text { expected to do for the } \\
\text { course (e.g., clear } \\
\text { instructions for deadline) } \\
\text { or give examples about } \\
\text { assignments }\end{array}$ & $\begin{array}{l}\text { "Not all but most of my instructors give } \\
\text { details on what they want in an assignment. } \\
\text { Sometimes it can be misleading to students } \\
\text { and [students] completed in a different way } \\
\text { but not the way the instructor had wanted." } \\
\text { "Having easy to follow and descriptive } \\
\text { instructions as well as samples greatly helps } \\
\text { to complete assignments correctly." }\end{array}$ & $19 \%$ \\
\hline Timely response & $\begin{array}{l}\text { Instructors respond to (or } \\
\text { answering) students' } \\
\text { emails/posts on discussion } \\
\text { board in a timely manner } \\
\text { and frequently. }\end{array}$ & $\begin{array}{l}\text { "When they respond to their email in a } \\
\text { timely manner. This helps because I can get } \\
\text { the assignment done without waiting too } \\
\text { long." } \\
\text { "Being very responsive to emails and } \\
\text { questions." }\end{array}$ & $17 \%$ \\
\hline $\begin{array}{l}\text { Regular } \\
\text { announcements } \\
\text { and } \\
\text { reminders }\end{array}$ & $\begin{array}{l}\text { Instructors send weekly } \\
\text { announcements or } \\
\text { reminders about the due } \\
\text { dates of assignments or } \\
\text { upcoming exams. }\end{array}$ & $\begin{array}{l}\text { "My biology teacher sends updates about } \\
\text { assignments which helps me to stay on track } \\
\text { in my class." } \\
\text { "The professors send plenty of notice via } \\
\text { email or blackboard announcements to alert } \\
\text { everyone to what is due even though we } \\
\text { have the syllabus as reference." }\end{array}$ & $10 \%$ \\
\hline $\begin{array}{l}\text { Quality feedback } \\
\text { on assignments }\end{array}$ & $\begin{array}{l}\text { Instructors give detailed, } \\
\text { constructive/ clear } \\
\text { feedback on assignments }\end{array}$ & $\begin{array}{l}\text { "The thing that helps me the most is when } \\
\text { they comment on the work I have done. It } \\
\text { helps me to understand what they are looking } \\
\text { for." } \\
\text { "Most try to give you feedback on work } \\
\text { completed. Try to help with positive } \\
\text { feedback." }\end{array}$ & $7 \%$ \\
\hline $\begin{array}{l}\text { Explaining the } \\
\text { course content with } \\
\text { concrete examples }\end{array}$ & $\begin{array}{l}\text { Instructors provide good } \\
\text { examples to help students } \\
\text { understand the course } \\
\text { content. }\end{array}$ & $\begin{array}{l}\text { "[The instructor] explains what we are doing } \\
\text { and gives an example of the concept in his } \\
\text { life. This helps me understand the concepts } \\
\text { better. } \\
\text { "I prefer some explanation and a lot of } \\
\text { examples of calculations." }\end{array}$ & $6 \%$ \\
\hline
\end{tabular}




\section{Table D3}

Themes of Ineffective Instructional Practices from Instructor Survey

\begin{tabular}{|c|c|c|c|}
\hline Themes & Definition & Sample Responses & Frequency \\
\hline $\begin{array}{l}\text { Poor attendance in } \\
\text { synchronous class } \\
\text { meetings }\end{array}$ & $\begin{array}{l}\text { When instructors hold } \\
\text { synchronous sessions } \\
\text { (e.g., Adobe Connect), } \\
\text { very few students attend } \\
\text { actively. }\end{array}$ & $\begin{array}{l}\text { "I have attempted many attempts at synchronous } \\
\text { meetings. We have made this a very easy process for } \\
\text { our students, but the majority of students do not prefer } \\
\text { to meet synchronously. The majority of our students } \\
\text { live in an asynchronous world where they would rather } \\
\text { text than make a phone call." } \\
\text { "We have tried doing a F2F training session along } \\
\text { with a synchronous session with faculty and had low } \\
\text { attendance with the synchronous sessions." }\end{array}$ & $25 \%$ \\
\hline $\begin{array}{l}\text { Lack of high- } \\
\text { quality engagement } \\
\text { in the discussion } \\
\text { forum }\end{array}$ & $\begin{array}{l}\text { It is challenging to } \\
\text { stimulate a high-quality } \\
\text { discussion via the } \\
\text { discussion board in this } \\
\text { course. }\end{array}$ & $\begin{array}{l}\text { "If I do not require that students respond to a } \\
\text { discussion post a day or two after posting their own } \\
\text { response, they never go back and read the thoughts of } \\
\text { others." } \\
\text { I require peer feedback on discussion boards. } \\
\text { However, some students regularly wait until the last } \\
\text { day to post and never respond to a peer." } \\
\text { "Stimulating quality discussions has been a } \\
\text { challenge." }\end{array}$ & $21 \%$ \\
\hline $\begin{array}{l}\text { Unsuccessful group } \\
\text { projects }\end{array}$ & $\begin{array}{l}\text { Students' group projects } \\
\text { and collaborative work } \\
\text { are not successful. }\end{array}$ & $\begin{array}{l}\text { "I tried a collaborative Wiki page as a weekly } \\
\text { assignment, but about half the groups seemed to have } \\
\text { trouble figuring out how to collaborate." } \\
\text { "I tried creating teams to work together and turn in } \\
\text { homework. That generated complaints as some } \\
\text { students felt that others were not actively participating } \\
\text { and should not receive the same grade as others who } \\
\text { were actively involved." } \\
\text { "Group projects have not been as successful as I would } \\
\text { like." }\end{array}$ & $12 \%$ \\
\hline $\begin{array}{l}\text { Problems } \\
\text { surrounding } \\
\text { deadlines }\end{array}$ & $\begin{array}{l}\text { When the due dates are } \\
\text { set up in a way that is } \\
\text { not consistent or too } \\
\text { flexible, it undermines } \\
\text { students' learning. }\end{array}$ & $\begin{array}{l}\text { "I tried providing due date extensions and the same } \\
\text { students would regularly 'take advantage' of the } \\
\text { opportunity. This will cause those same students to fall } \\
\text { further and further behind and they will consistently } \\
\text { ask for extensions. Surprisingly, I have had at least } \\
\text { two students per semester who will not follow due } \\
\text { dates but consistently ask for extensions." } \\
\text { "Having inconsistent due dates caused students to miss } \\
\text { assignments." }\end{array}$ & $7 \%$ \\
\hline
\end{tabular}




\section{Table D4}

Themes of Ineffective Instructional Practices from Student Survey

\begin{tabular}{|c|c|c|c|}
\hline Themes & Definition & Sample Responses & Frequency \\
\hline $\begin{array}{l}\text { Insufficient } \\
\text { instructor } \\
\text { communication and } \\
\text { engagement }\end{array}$ & $\begin{array}{l}\text { The instructors lack } \\
\text { communication, do not } \\
\text { engage with the } \\
\text { students, or do not make } \\
\text { themselves available to } \\
\text { students. }\end{array}$ & $\begin{array}{l}\text { "The majority of the instructors are not really } \\
\text { involved in my online classes. If I am lucky I might } \\
\text { hear from them once or twice during the semester } \\
\text { to remind me to do some assignment or take a test." } \\
\text { "I didn't like their lack of communication. Their } \\
\text { lack of communication was so bad." }\end{array}$ & $25 \%$ \\
\hline $\begin{array}{l}\text { Unclear } \\
\text { expectations on } \\
\text { course assignments }\end{array}$ & $\begin{array}{l}\text { The instructors fail to } \\
\text { make course } \\
\text { assignments (e.g., } \\
\text { deadlines) easy to find } \\
\text { and understand and } \\
\text { sometimes do not } \\
\text { provide timely and } \\
\text { correct information on } \\
\text { course requirements. }\end{array}$ & $\begin{array}{l}\text { "Sometimes forget to give examples to help } \\
\text { understand the concept of the assignment and what } \\
\text { exactly the instructor is looking for." } \\
\text { "Sometimes, instructions for certain assignments } \\
\text { are so vague that you have no idea what you are } \\
\text { supposed to do." }\end{array}$ & $23 \%$ \\
\hline $\begin{array}{l}\text { Unreasonable } \\
\text { workload }\end{array}$ & $\begin{array}{l}\text { The course requires } \\
\text { unreasonable work that } \\
\text { is sometimes } \\
\text { unnecessary or not } \\
\text { meaningful for learning. }\end{array}$ & $\begin{array}{l}\text { "Instructors do not give a fair course load. A lot of } \\
\text { us take online classes because we're older, work } \\
\text { full time, have families and the course load is } \\
\text { meant for kids who don't have much going on } \\
\text { outside of school." } \\
\text { "I feel sometimes online courses are so jam- } \\
\text { packed with busy work that I focus on getting } \\
\text { assignments done and don't really retain the } \\
\text { information." } \\
\text { "Give unnecessary work online when they don't } \\
\text { give the same in seated courses." }\end{array}$ & $11 \%$ \\
\hline $\begin{array}{l}\text { Insufficient } \\
\text { feedback on } \\
\text { assignments and } \\
\text { assessments }\end{array}$ & $\begin{array}{l}\text { Instructors fails to } \\
\text { provide timely or } \\
\text { detailed feedback on } \\
\text { assignments or } \\
\text { assessments }\end{array}$ & $\begin{array}{l}\text { "Wait to the last minute to grade assignments and } \\
\text { don't give feedback. This causes the students to } \\
\text { work in the dark, not knowing if the assignment } \\
\text { they completed was correct or not before they } \\
\text { submit another assignment." } \\
\text { "If the instructor takes a while to give you feedback } \\
\text { that could impact your grade because you won't } \\
\text { know what to improve on until you get the grade." }\end{array}$ & $9 \%$ \\
\hline
\end{tabular}




\section{Table D5}

Themes of Changes Needed to Improve Online Instructions from Instructor Survey

\begin{tabular}{|c|c|c|c|}
\hline Themes & Definition & Sample Responses & $\begin{array}{l}\text { Freq } \\
\text { uency }\end{array}$ \\
\hline
\end{tabular}

$\begin{array}{lll}\begin{array}{l}\text { Improving } \\ \text { instructor }\end{array} & \begin{array}{l}\text { Instructors are more } \\ \text { engaged with the }\end{array} & \begin{array}{l}\text { "I think it is very important to make personal contact with } \\ \text { students, especially those who are having a difficult time. } \\ \text { communication } \\ \text { and engagement }\end{array} \\ \begin{array}{l}\text { course in general and } \\ \text { improve the level and harder for them to drop or fail if they have a relation } \\ \text { quality of } \\ \text { communication. }\end{array} & \begin{array}{l}\text { "A high level of faculty-student communication. Greater } \\ \text { instructor engagement with students." }\end{array}\end{array}$

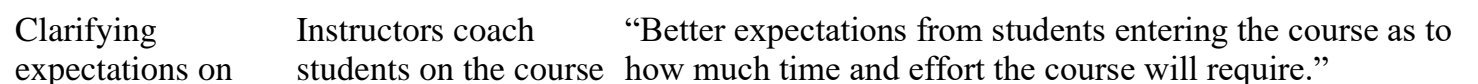
expectations on online learning students on the course requirement and the amount of time and the skills necessary to be successful in online learning.
$18 \%$

"Online students should know up front (prior to registration): the general time commitment per week to be successful in the course; the number of assignments due and when they are due; the computer requirements for course; how late assignments are handled."

"For me personally, I have provided my students with multiple $10 \%$

Delivering content Instructors use multiple instructional materials to illustrate using varied materials and diversified media the course content.

resources in order to make them successful. I am continuing to add anything I am made aware of in order to help my students."
"I think students need to have video examples available not just a textbook."

Providing timely response

Instructors respond to or answer students' emails or posts on the discussion board in a timely manner and frequently.

"Respond timely to students when they have a technical problem, or questions. If it takes days to get a response, or students don't get a response at all, it defeats the learning experience, and conveys a lack of caring to students."

"To be more responsive to students outside of the 8-to-5 Monday - Friday schedule."

Instructors give detailed/constructive/ clear feedback on assignments

Improving feedback on assignments and assessments

Improving feedback on student progress
Instructors monitor students' course progress and provide feedback on their course progress.
"Detailed and timely feedback on assignments. The instructor should provide instructive feedback anytime a student does not receive a perfect score."

"Instructors should know how to set up a course in Moodle so students have immediate weekly feedback regarding assignments and their overall progress in the course."

\footnotetext{
"More automatic monitoring and feedback of student progress, starting early in the term with attendance and completion of early assignments."

"Instructors should know how to set up a course in Moodle so students have immediate weekly feedback regarding assignments and their overall progress in the course."
} 
Table D6

Themes of Changes Needed to Improve Online Instructions from Student Survey

\begin{tabular}{llll} 
Category & Definition & \multicolumn{1}{c}{ Sample Responses } & Frequency \\
\hline $\begin{array}{lll}\text { Delivering } \\
\text { content using }\end{array}$ & $\begin{array}{l}\text { Instructors use multiple } \\
\text { instructional materials to }\end{array}$ & "I like when teachers video themselves explaining the lessons. & $10 \%$ \\
varied & illustrate the course & it really helps, especially for those who are audible learners." \\
materials and & content. & "I would prefer to read text, watch lectures, and take online \\
diversified & & quizzes and tests on what I had read in the book."
\end{tabular}

media

Setting up deadlines in more reasonable ways

$\begin{array}{ll}\text { Improving } & \text { Instructors incorporate } \\ \text { discussion } & \text { discussion board } \\ \text { board } & \text { activities to encourage } \\ \text { activities } & \text { student-student } \\ & \text { interaction. }\end{array}$

Sending Instructors send weekly regular announcements or Instructors set up more reasonable due dates.

announcement reminders about the due $s$ and dates of assignments, reminders

Providing timely response

Improving feedback on assignments and assessments

Instructors give
detailed/constructive/ clear
feedback on assignments

Sending regular Instructors send weekly announcements announcements or and reminders reminders about due dates of assignments, upcoming exams etc. upcoming exams etc.

Instructors respond to or answer students' emails or posts on discussion board in a timely manner and frequently.
"More professors to post due dates for assignments as early as possible for students who may need to work ahead for whatever reason."

"Classes having due dates during the week and not on weekends. Assignments shouldn't be due on a Saturday night because the weekend is our time off from school."

"I wish the due dates in assignments weren't so close together or an assignment every week. When you stack on classes keeping up with work for two different classes that is due that same week is hard."

"Students are typically forced to respond to a certain amount of people which ends up not being a productive discussion. There needs to be more back and forth discussion about intriguing topics."

"Meaningful discussion boards, not just busy work where others give a 'me too' response."

"It would be really cool to get notifications on your phone just $4 \%$ like a text with reminders of what's due soon!"

"Set up a reminder system with students. Try Remind 101 to keep students up to date."

"To be more successful I need professors to respond to their emails in a timely matter... sometimes their help is extremely needed when taking an online course."

"Having assistants to answer email questions since the professor will be busy, this way the student can quickly get a response to their question."

"When I get a question wrong, I would like a complete answer on where the answer can be found in the text and why it is wrong." "More feedback from the teachers. When I get a question wrong, I would like a complete answer on where the answer can be found in the text and why it is wrong."

"It would be really cool to get notifications on your phone just like a text with reminders of what's due soon!"

"Set up a reminder system with students. Try Remind 101 to keep students up to date." 